\title{
COMPARISON OF GLOBAL REGULATORY GUIDELINES FOR AVAILABILITY OF DIFFERENT BIOWAIVER PROVISIONS AND APPLICATION REQUIREMENTS OF BIOPHARMACEUTICS CLASSIFICATION SYSTEM (BCS) BASED BIOWAIVER.
}

\author{
Available Internet at www.ijdra.com \\ REVIEW ARTICLE \\ ${ }^{1}$ Patel Jimi, ${ }^{1}$ Mehta Priti ${ }^{*}{ }^{2}$ Kothari Vaishali \\ ${ }^{1}$ Dept of Pharm. Analysis, Institute of Pharmacy, Nirma University, Ahmedabad - 382481 \\ ${ }^{2}$ International Regulatory Affairs, Cadila Healthcare Limited,, Ahmedabad - 380059 \\ *Corresponding Author's E-mail: drpritimehta@nirmauni.ac.in
}

\begin{abstract}
To waive a complete and systemic Bioequivalence (BE) study, Biowaiver or Request for a Biowaiver is a fast track approach to boost the drug development process. Over the past three-four years the Biowaiver market shows greater number of Biowaiver submissions and the wider use of In-vitro permeability study. Biowaiver is a beneficial approach for getting approval of Abbreviated New Drug Application (ANDA) while, BCS based Biowaiver is the novel approach to gain approval for New Drug Application (NDA) as well as ANDA. A Biopharmaceutics Classification System (BCS) based Biowaiver is an exemption from conducting human bioequivalence studies when active ingredient and dosage form meet criteria of solubility, permeability and dissolution. The Paper covers different kind of Biowaiver approaches and the criteria for the applicability of BCS based Biowaivers in the different geographic scopes with regard to global development strategy. There is a comparison of global guidelines on provisions availability for different types of Biowaiver approaches as well as for requirements of Biowaiver based on BCS. From comparison of different global guidelines it is reviewed that most of the guidance resembles to the USFDA, EU and WHO guidelines because most of the regulatory authorities are following the BCS based Biowaiver concept as one of the three main guidance documents (USFDA, EMA, WHO) or a combination of specific requirements.
\end{abstract}

Keywords: Bioequivalence, Biowaiver, BCS based Biowaiver.

\section{INTRODUCTION}

As per survey of FDA, every year only 18 to 26 New Chemical Entities (NCEs) get approved as a New Drug Application (NDA). Whereas, pharmaceutical companies file thousands of Abbreviated New Drug Applications (ANDAs) to get an approval as a generic version of innovators every year. To get an approval for ANDAs, generic formulation should be proven bioequivalent to that of Reference Listed Drug (RLD). For market authorization of generics, instead of non-clinical and clinical studies, only Bioequivalence (BE) study is required. At drug development stage, only one formulation becomes eligible for marketing from many of formulations. In that case, Biowaiver concept comes into picture to reduce unnecessary time and expense of BE study for each formulation.
Biowaiver is a kind of ANDA filing, which applies to reduce time and cost from a complete, systemic BE study.

\section{Biowaiver}

Simply, Biowaiver is considered as waiver of clinical bioequivalence studies. As per WHO guidance, "The term Biowaiver is applied to a regulatory drug approval process when the dossier (application) is approved based on evidence of equivalence other than In-vivo bioequivalence test."

\section{Different Approaches for Biowaiver}

Different drug regulatory authorities approve Biowaiver for different conditions, which are summarized in Figure 1 and described below in brief. 


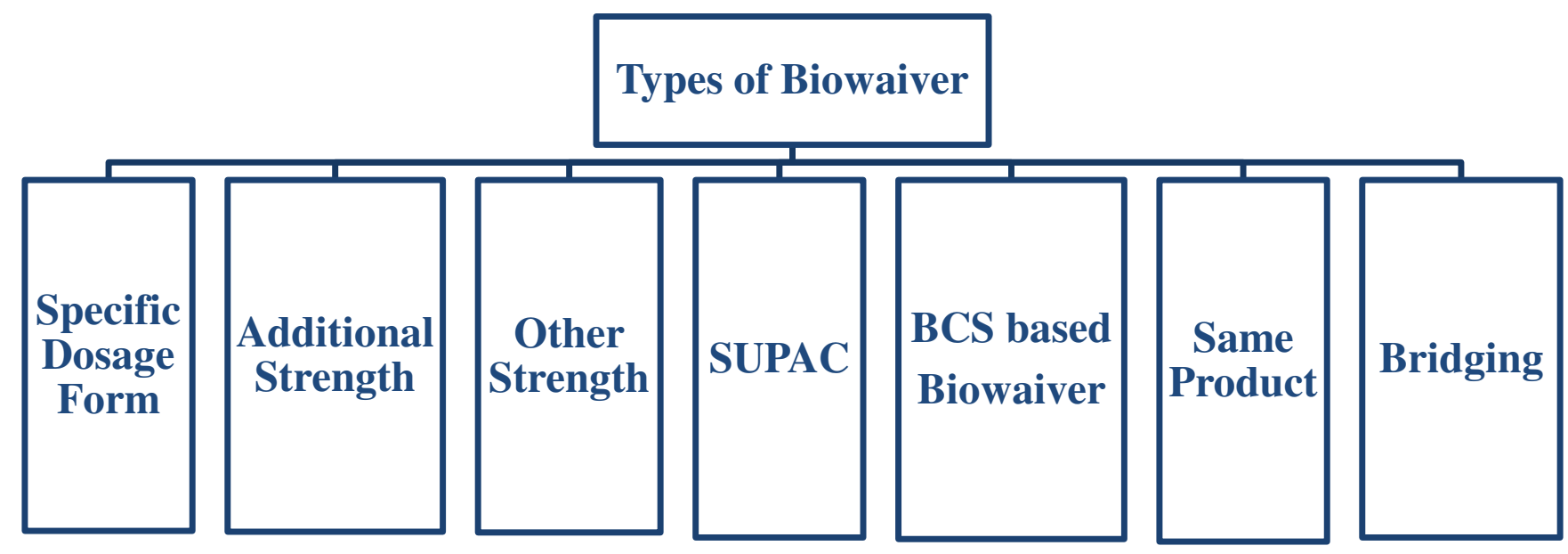

Figure1. Different Approaches of Biowaiver

\section{1) Biowaiver for Specific Dosage Forms}

Due to certain characteristics of some specific formulations, BE study may not be required. In that case, bioequivalence between the test and the reference product can be presumed without any further In-vivo experiments. This kind of Biowaiver can be possible for aqueous oral solutions, parenteral solutions and topical solutions (e.g. eye drops). One of the major prerequisite is that the excipients should not influence the bioavailability of the active drug substance. The conditions for this Biowaiver are identical in most countries.

\section{2) Biowaiver for Additional Dose Strengths}

If several strengths of a generic drug product are developed for the same formulation then under this approach, it can be sufficient to demonstrate bioequivalence of test versus the reference product only with one or two strengths, depending on certain product characteristics, rather than performing $\mathrm{BE}$ study for all designed strengths. Also for this Biowaiver, the basic requirements are identical in most countries.

For this type of Biowaiver, BE study is performed either for the highest or lowest strength among several strengths, in the case of linear Pharmacokinetic profile. The highest or lowest strength study based on pharmacokinetic profile of different strength means that if there is linear relationship between dose $\mathrm{Vs}$ response of several strengths, then only BE study can be performed either for highest or lowest strength.
Choice of strength for BE study: (In case of Additional Strength) (1)

Highest Strength: Mostly highest strength is used for BE study. Moreover, if lowest strength is undetectable by analytical method then also highest strength is used to perform BE study.

Lowest Strength: When highest strength is not tolerated by patient or if the highest strength is the issue of patient safety in that case lowest strength is used for BE study.

When highest and lowest both strengths are issue in that case, strength other than highest and lowest is used for BE study among several strengths.

If there is some deviation from quantitatively proportional composition, then one or more of the following criteria applies to the strength used in the bioequivalence study and the strength(s) for which a waiver is to be granted.

(1)

The amount of the active substance(s) is less than $5 \%$ of the tablet core weight, the weight of the capsule content.

$>$ The amounts of the different core excipients or capsule content are the same for the concerned strength and the amount of active substance is changed.

$>$ The amount of filler is changed to account for the change in amount of active substance. The amounts of other core excipients or capsule content should be the same for the concerned strengths. 
$>$ Appropriate In-vitro dissolution data should confirm the adequacy of waiving additional In-vivo bioequivalence testing.

\section{3) Biowaiver for Other Strengths}

If several strengths (which are already approved) are designed for same formulation then it is called "Biowaiver based on Other Strength". Mostly highest or lowest strength (In case of linear pharmacokinetic) are used for BE study.

There are two approaches under Biowaiver for Other Strengths.

First approach called "Look a Like" is used under Biowaiver for other strength, where difference of total weight and size of different strengths is minor. Waiver of In-vivo studies for different strengths of a drug product can be granted under 21CFR 320.22 (d) (2) when (1)

The drug product is in the same dosage form, but in a different strength;

$>$ This different strength is proportionally similar in its active and inactive ingredients to the strength of the product for which the same manufacturer has conducted an appropriate In-vivo study;

$>$ The composition of strengths are quantitatively proportional, i.e. the ratio between the amount of each excipient to the amount of active substance(s) is the same for all strengths (for immediate release products coating components, capsule shell, color agents and flavors are not required to follow this rule).

A second approach is called "Dose Proportional." For that guidance defines proportionally similar in the following ways: (1)

$>$ All active and inactive ingredients are in exactly the same proportion between different strengths (e.g., a tablet of $50 \mathrm{mg}$ strength has all the inactive ingredients, exactly half that of a tablet of $100 \mathrm{mg}$ strength, and twice that of a tablet of $25 \mathrm{mg}$ strength).

$>$ Active and inactive ingredients are not in exactly the same proportional between different strengths as stated above, but the ratios of inactive ingredients to total weight of the dosage form are within the limits defined by the SUPAC-IR and SUPAC-MR guidance up to and including Level II.

$>$ For high potency drug substances, where are amount of the active drug substance in the dosage form is relatively low, the total weight of the dosage form remains nearly the same for all strengths (within $\pm 10 \%$ of the total weight of the strength on which a biostudy was performed), the same inactive ingredients are used for all strengths and the change in any strength is obtained by altering the amount of the active ingredients and one or more of the inactive ingredients. The changes in the inactive ingredients are within the limits defined by the SUPAC-IR and SUPAC-MR guidance up to and including Level II.

\section{4) Biowaiver based on BCS}

For drug substances belonging to a BCS class (Mostly Class I or Class III), a complete Biowaiver for bioequivalence studies might be possible if criteria of solubility, permeability and dissolution are met. The eligibility criteria for BCS based Biowaivers differs between USA, EU and WHO as well as in other countries which have been compared in table 3 on basis of solubility, permeability, dissolution and BCS Classification.

\section{5) Biowaiver for Scale Up and Post Approval Changes (SUPAC)}

During the life cycle of a medicinal product, there usually are several post approval changes which may require bioequivalence study to prove the equivalence of the new generic medicinal product to the reference product. However, under this approach there is no need of additional BE study as the applicant can justify that certain preconditions are fulfilled or comparable in different geographical scopes. This kind of Biowaiver is applicable to mostly minor post approval changes and few of the moderate changes.

Information of the types of In-vitro dissolution testing in the presence of specified post approval changes are provided in FDA guidance for industry entitled SUPAC-IR: Immediate Release Solid Oral Dosage Forms - Scale Up and Post Approval Changes. For post approval changes, we recommended that the In-vitro comparison be made between the pre-change and post- 
change products. In instances where dissolution profile comparisons are suggested, we also recommended an $\mathrm{f} 2$ test be used. An $\mathrm{f} 2$ value of $>50$ suggests a sufficiently similar dissolution profile such that no further In-vivo studies are needed. When In-vivo BE studies are called for, we recommend that the comparison be made for ANDAs between the post-change and RLD.

\section{6) Biowaiver for Same Product}

Biowaiver for same product can be granted if the generic medicinal product is a one-to-one copy of the reference product, bioequivalence between the test and reference product can be presumed based on demonstration of identity and comparative In-vitro dissolution data. The basis for this Biowaiver approach is the equivalence of the test and reference product. Although not officially described in regulatory guidance documents, in theory it is possible only if the generic applicant knows exact quantitative and qualitative composition (with regard to active substance(s) and excipients) as well as the galenical characteristics and manufacturing process of the reference product. In practice, however, it is often not feasible due to patent issues to develop quantitatively and qualitatively the same product as the innovator. Altogether, this approach is not very common but it sometimes is possible (e.g. simple gelatin capsules filled only with the active ingredient without any excipients). Regulatory authorities worldwide must be convinced of this Biowaiver approach on a case by case basis.

\section{7) Bridging - Biowaiver for National Bioequivalence Study based on Bioequivalence Study versus Foreign reference Product}

There is the so called "Bridging" approach used to waive unnecessary national bioequivalence studies. Many countries require so-called local bioequivalence studies that are bioequivalence studies of test product versus the local reference product; very often performed with subjects from the local population. Asian countries (instance e.g., China, South Korea, Thailand and Japan) usually require such local bioequivalence studies. Other countries such as Russia, Canada, Australia, Brazil, Mexico require bioequivalence studies versus the corresponding local reference product. In the case of ethnic sensitivity relating to the metabolism of the drug substance, it makes sense to demonstrate bioequivalence in different ethnic populations. However, the need to use the local reference product is not always justified or necessary because innovator products are very often identical in different countries around the world.

Under this "Bridging" Biowaiver concept, regulatory authorities accept the results of bioequivalence studies which have been performed for test versus a foreign reference product rather than national reference product approved in the country where the application is made. The study results versus the foreign reference product are "bridged" via product likeness to the locally /nationally approved reference product. If the foreign and local/ national reference products are demonstrated to be essentially the same, an additional bioequivalence study may not be required. However, one prerequisite is that general study requirements like GCP are fulfilled and that potential ethnic differences in pharmacokinetics can be excluded.

\section{DISSCUSSION}

Various Biowaiver approaches have been described. These approaches are compared against global regulatory authorities in Table 1 . The symbol "+" indicates availability of provision in the guideline for the corresponding authority. The symbol "-." indicates absence of provision in the guideline for the corresponding authority. 
Table 1: Comparison on Provisions Available for Different Biowaiver Approaches

\begin{tabular}{|c|c|c|c|c|c|c|c|}
\hline $\begin{array}{l}\text { Parameter } \\
\text { Regulatory } \\
\text { Authority }\end{array}$ & $\begin{array}{c}\text { Specific } \\
\text { Dosage } \\
\text { Form }\end{array}$ & $\begin{array}{c}\text { Additional } \\
\text { strengths } \\
\text {-Lower } \\
\text {-higher }\end{array}$ & $\begin{array}{c}\text { Other } \\
\text { Strengths }\end{array}$ & $\begin{array}{c}\text { BCS } \\
\text { Based }\end{array}$ & $\begin{array}{c}\text { Post } \\
\text { Approval } \\
\text { Changes }\end{array}$ & $\begin{array}{c}\text { Same } \\
\text { Product }\end{array}$ & Bridging \\
\hline USA & + & + & + & $\begin{array}{c}+ \\
\text { Class I }\end{array}$ & + & + & + \\
\hline $\mathbf{E U}$ & + & $\begin{array}{c}+ \\
\text { Highest \& } \\
\text { Lowest }\end{array}$ & + & $\begin{array}{c}+ \\
\text { Class I \& } \\
\text { Class III }\end{array}$ & + & + & + \\
\hline WHO & + & + & - & $\begin{array}{c}+ \\
\text { Class I, } \\
\text { Class III } \\
\text { \& Class II } \\
\text { weak acid }\end{array}$ & + & + & - \\
\hline ASEAN & + & $\begin{array}{c}+ \\
\text { Highest \& } \\
\text { Lowest }\end{array}$ & + & $\begin{array}{c}+ \\
\text { Class I }\end{array}$ & + & + & - \\
\hline Australia & + & $\begin{array}{c}+ \\
\text { Highest \& } \\
\text { Lowest }\end{array}$ & + & $\begin{array}{c}+ \\
\text { Class I \& } \\
\text { Class III }\end{array}$ & + & + & + \\
\hline Brazil & + & $\begin{array}{c}+ \\
\text { Highest \& } \\
\text { Lowest }\end{array}$ & - & $\begin{array}{c}+ \\
\text { Class I }\end{array}$ & + & + & - \\
\hline Canada & + & + & - & $\begin{array}{c}+ \\
\text { Class I \& } \\
\text { Class III }\end{array}$ & + & + & - \\
\hline China & & slated Guidar & e from Reg & atory Autho & $y$ of China & s not avail & able. \\
\hline India & + & + & - & $\begin{array}{c}+ \\
\text { Class I }\end{array}$ & + & + & - \\
\hline Japan & + & + & + & $\begin{array}{c}\text { Not } \\
\text { Available }\end{array}$ & + & + & - \\
\hline Malaysia & + & $\begin{array}{c}+ \\
\text { Highest \& } \\
\text { Lowest }\end{array}$ & + & $\begin{array}{c}+ \\
\text { Class I }\end{array}$ & + & + & + \\
\hline Russia & + & + & - & $\begin{array}{c}+ \\
\text { Class I }\end{array}$ & + & + & - \\
\hline $\begin{array}{l}\text { Saudi } \\
\text { Arabia }\end{array}$ & + & + & - & $\begin{array}{c}+ \\
\text { Class I }\end{array}$ & + & + & + \\
\hline $\begin{array}{l}\text { South } \\
\text { Africa }\end{array}$ & + & + & - & $\begin{array}{c}+ \\
\text { Class I }\end{array}$ & + & + & - \\
\hline
\end{tabular}


From comparison of availability of Biowaiver approaches, it can be seen that provisions of specific dosage form, BCS based, Post Approval Changes, Same Product based Biowaiver and Additional Strength Biowaiver (Highest or Lowest) are available in multiple regulatory authorities. However, in most countries, y highest strength $\mathrm{BE}$ study is essential to perform. Moreover, BCS based Biowaiver approach is not available in all countries, specifically Japan and Switzerland among the compared regulatory authorities. In addition, BCS class (Mostly BCS Class I or Class III) requirement for Biowaiver also varies. It is significant to note that Biowaiver based on Other Strengths is available only in the EU, ASEAN, Australia and Malaysia. Biowaiver based on "Bridging Approach" is available in only the USA, EU, Malaysia and Saudi Arabia.

\section{BCS BASED BIOWAIVER}

A Biowaiver can currently be requested for solid orally administered immediate release product containing the drug having high solubility and high permeability (BCS based Biowaiver). Statistics on generic drug products approved by USFDA between 2000 and 2011 based on BCS classification include 263 approvals, of which 110 approvals were for BCS Class I, 55 approvals for BCS Class II and 98 approvals for BCS Class III. (2)

It is estimated that the In-vivo bioavailability and bioequivalence studies cost up to $\$ 250,000$ each and require up to 2 months to complete, whereas the In-vitro laboratory tests are rather inexpensive and fast. BCS based Biowaiver is applicable to ANDA as well as NDA filing whichever applies, exempting from performing In-vivo bioequivalence (BE) study and reducing cost and time to complete BE study.

A BCS based Biowaiver is an exemption from conducting human bioequivalence studies if active ingredient and dosage form meet solubility, In-vitro permeability and dissolution criteria. As per Biopharmaceutics Classification System (BCS), Drugs are classified into four classes having different solubility and permeability criteria, described in Table 2 .
Table 2: Biopharmaceutical Classification

\begin{tabular}{|c|c|}
\hline BCS Class I & BCS Class II \\
High Solubility & Low Solubility \\
High Permeability & High Permeability \\
\hline BCS Class III & BCS Class IV \\
High Solubility & Low Solubility \\
Low Permeability & Low Permeability \\
\hline
\end{tabular}

Different guidelines for regulatory authorities have their own requirements and criteria for submitting dossier to get BCS based Biowaiver, and for carrying out study needed for BCS based Biowaiver. The Approval criteria vary by regulatory authority, but most of the guidelines have the same requirements for permeability, solubility and dissolution because most of them are adopted from USFDA, EMEA and WHO guidance on BCS based Biowaiver.

Jurisdictions like Brazil, Australia, Association of Southeast Asian Nations (ASEAN), South Africa, India, and Saudi Arabia have adopted the BCS based Biowaiver concept based on one of the three main guidance documents (USFDA, EMA, WHO) or a combinations of specific requirements from each guidance. As per WHO guideline, BCS based Biowaiver can be granted either for BCS Class I or Class III or Class II weak acids. But most of drug regulatory authority are granting BCS based Biowaiver for BCS class I drugs. Whereas EU, Australia and Canada regulatory guideline have provision to grant Biowaiver for BCS Class I as well as BCS Class III.

Although most of the requirements for BCS based Biowaiver are the same for solubility, permeability and dissolution, the $\mathrm{pH}$ range for solubility study, extent of absorption and BCS Class vary by regulatory authority, indicated in bold fonts in Table 3. Table 3 presents the comparison between requirements for data to support BCS based Biowaiver is given. 
Table 3: Comparison of Key Factors or Requirement Criteria for BCS Based Biowaiver

\begin{tabular}{|c|c|c|c|c|}
\hline $\begin{array}{l}\text { Regulatory } \\
\text { Authority }\end{array}$ & Solubility of Drug Substance & Permeability of Drug Substance & $\begin{array}{c}\text { BCS Class } \\
\text { of Drug } \\
\text { Substance }\end{array}$ & $\begin{array}{l}\text { In-vitro Dissolution Similarity of Test and Reference } \\
\text { Product }\end{array}$ \\
\hline USA (3) * & $\begin{array}{l}\text { Highest dose strength is } \\
\text { soluble in } \leq 250 \mathrm{ml} \text { of } \\
\text { buffers } \\
\text { pH range: } \\
\text { 1-7.5 } \\
\text { Temp.: } \\
37 \pm 1^{\circ} \mathrm{C} \\
\text { Methodology: } \\
\text { - Shake Flask Method } \\
\text { - Acid or Base Titration }\end{array}$ & $\begin{array}{l}\text { Highly Permeable: Extent of } \\
\text { absorption in humans is } \geq \mathbf{9 0 \%} \\
\text { Methodology: } \\
\text { - Absolute Bioavailability study } \\
\text { - Mass Balance study } \\
\text { - In-vivo perfusion study } \\
\text { - In-vitro excised human or } \\
\text { animal Intestinal study } \\
\text { - In-vitro epithelial cell culture } \\
\text { study }\end{array}$ & Class I & $\begin{array}{l}\text { Rapidly Dissolving: } \geq 85 \% \text { of the labeled amount of the } \\
\text { drug substance dissolves within } 30 \text { minutes. } \\
\text { Apparatus: USP Type I at } 100 \mathrm{rpm} \text { or Type II at } 50 \mathrm{rpm} \\
\text { Dissolution Media: } 900 \mathrm{ml} \text { of following media } \\
\text { (1) } 0.1 \mathrm{~N} \mathrm{HCl} \text { or Simulated Gastric Fluid USP without } \\
\text { enzymes; } \\
\text { (2) pH } 4.5 \text { buffer; } \\
\text { (3) pH } 6.8 \text { buffer or Simulated Intestinal Fluid USP } \\
\text { without enzymes. } \\
\mathbf{N}=12\end{array}$ \\
\hline $\mathbf{E U}(4)$ & $\begin{array}{l}\text { Highest dose strength is } \\
\text { soluble in } \leq 250 \mathrm{ml} \text { of } \\
\text { buffers } \\
\text { pH range: } \\
\text { 1-6.8 } \\
\text { Temp.: } \\
37 \pm 1^{\circ} \mathrm{C} \\
\text { Methodology: } \\
\text { - Shake Flask Method }\end{array}$ & $\begin{array}{l}\text { Highly Permeable: Extent of } \\
\text { absorption in humans is } \geq \mathbf{8 5 \%} \\
\text { Methodology: } \\
\text { - Absolute Bioavailability study } \\
\text { - Mass Balance study }\end{array}$ & $\begin{array}{l}\text { Class I, } \\
\text { Class III }\end{array}$ & $\begin{array}{l}\text { Class I } \\
\text { Rapidly Dissolving: } \geq 85 \% \text { of the labeled amount of the } \\
\text { drug substance dissolves within } 30 \text { minutes. } \\
\text { Class III } \\
\text { Very Rapidly Dissolving: } \geq 85 \% \text { of the labeled amount } \\
\text { of the drug substance dissolves within } 15 \text { minutes. } \\
\text { Apparatus: USP Type I at } 100 \mathrm{rpm} \text { or Type II at } 50 \mathrm{rpm} \\
\text { Dissolution Media: } 900 \mathrm{ml} \text { of following media } \\
\text { (1) } 0.1 \mathrm{~N} \mathrm{HCl} \text { or Simulated Gastric Fluid USP without } \\
\text { enzymes; } \\
\text { (2) pH } 4.5 \text { buffer; } \\
\text { (3) pH } 6.8 \text { buffer or Simulated Intestinal Fluid USP } \\
\text { without enzymes. } \\
\mathbf{N}=12\end{array}$ \\
\hline
\end{tabular}




\begin{tabular}{|c|c|c|c|c|}
\hline $\begin{array}{c}\text { Regulatory } \\
\text { Authority }\end{array}$ & Solubility of Drug Substance & Permeability of Drug Substance & $\begin{array}{c}\text { BCS Class } \\
\text { of Drug } \\
\text { Substance }\end{array}$ & $\begin{array}{c}\text { In-vitro Dissolution Similarity of Test and Reference } \\
\text { Product }\end{array}$ \\
\hline WHO (5) & $\begin{array}{l}\text { Highest dose strength is } \\
\text { soluble in } \leq 250 \mathrm{ml} \text { of } \\
\text { buffers } \\
\text { pH range: } \\
\text { 1-6.8 } \\
\text { Temp.: } \\
37 \pm 1^{\circ} \mathrm{C} \\
\text { Methodology: } \\
\text { - Shake Flask Method }\end{array}$ & $\begin{array}{l}\text { Highly Permeable: Extent of } \\
\text { absorption in humans is } \geq \mathbf{8 5 \%} \\
\text { Methodology: } \\
\text { - Absolute Bioavailability study } \\
\text { - Mass Balance study }\end{array}$ & $\begin{array}{l}\text { Class I, } \\
\text { Class III } \\
\text { and Class } \\
\text { II weak } \\
\text { acid }\end{array}$ & $\begin{array}{l}\text { Rapidly Dissolving: } \\
\text { Class I: } \\
\geq 85 \% \text { of the labeled amount of the drug substance } \\
\text { dissolves within } 30 \text { minutes. } \\
\text { Class III: } \\
\geq 85 \% \text { of the labeled amount of the drug substance } \\
\text { dissolves within } 15 \text { minutes. } \\
\text { Class II(Weak Acid): } \\
\geq 85 \% \text { of the labeled amount of the drug substance } \\
\text { dissolves within } 30 \text { minutes at } \\
\text { pH } 6.8 \\
\text { Apparatus: USP Type I at } 100 \text { rpm or } \\
\text { Type II at } 75 \text { rpm } \\
\text { Dissolution Media: } 900 \text { ml of following media } \\
\text { (1) } 0.1 \mathrm{~N} \text { HCl or Simulated Gastric Fluid USP without } \\
\text { enzymes; } \\
\text { (2) pH } 4.5 \text { buffer; } \\
\text { (3) pH } 6.8 \text { buffer or Simulated Intestinal Fluid USP } \\
\text { without enzymes. } \\
\text { N = } 12\end{array}$ \\
\hline ASEAN (6) & $\begin{array}{l}\text { Highest dose strength is } \\
\text { soluble in } \leq 250 \mathrm{ml} \text { of } \\
\text { buffers } \\
\text { pH range: } \\
\text { 1-7.5 } \\
\text { Temp.: } \\
37 \pm 1^{\circ} \mathrm{C}\end{array}$ & $\begin{array}{l}\text { Highly Permeable: Extent of } \\
\text { absorption in humans is } \geq \mathbf{9 0 \%} \\
\text { Methodology: } \\
\text { - Absolute Bioavailability study } \\
\text { - Mass Balance study } \\
\text { - In-vivo perfusion study }\end{array}$ & Class I & $\begin{array}{l}\text { Rapidly Dissolving: } \geq 85 \% \text { of the labeled amount of the } \\
\text { drug substance dissolves within } 30 \text { minutes. } \\
\text { Apparatus: USP Type I at } 100 \mathrm{rpm} \text { or Type II at } 50 \mathrm{rpm} \\
\text { Dissolution Media: } 900 \mathrm{ml} \text { of following media } \\
\text { (1) } 0.1 \mathrm{~N} \mathrm{HCl} \text { or Simulated Gastric Fluid USP without } \\
\text { enzymes; } \\
\text { (2) } \mathrm{pH} 4.5 \text { buffer; }\end{array}$ \\
\hline
\end{tabular}




\begin{tabular}{|c|c|c|c|c|}
\hline $\begin{array}{l}\text { Regulatory } \\
\text { Authority }\end{array}$ & Solubility of Drug Substance & Permeability of Drug Substance & $\begin{array}{l}\text { BCS Class } \\
\text { of Drug } \\
\text { Substance }\end{array}$ & $\begin{array}{l}\text { In-vitro Dissolution Similarity of Test and Reference } \\
\text { Product }\end{array}$ \\
\hline & $\begin{array}{l}\text { Methodology: } \\
\text { - Shake Flask Method, } \\
\text { - } \quad \text { Acid or Base Titration }\end{array}$ & $\begin{array}{l}\text { - In-vitro excised human or } \\
\text { animal Intestinal study } \\
\text { - In-vitro epithelial cell culture } \\
\text { study }\end{array}$ & & $\begin{array}{l}\text { (3) } \mathrm{pH} 6.8 \text { buffer or Simulated Intestinal Fluid USP } \\
\text { without enzymes. } \\
\mathbf{N}=12\end{array}$ \\
\hline Australia(4) & $\begin{array}{l}\text { Highest dose strength is } \\
\text { soluble in } \leq 250 \mathrm{ml} \text { of } \\
\text { buffers } \\
\text { pH range: } \\
\text { 1-6.8 } \\
\text { Temp.: } \\
37 \pm 1^{\circ} \mathrm{C} \\
\text { Methodology: } \\
\text { - Shake Flask Method }\end{array}$ & $\begin{array}{l}\text { Highly Permeable: Extent of } \\
\text { absorption in humans is } \geq \mathbf{8 5 \%} \\
\text { Methodology: } \\
\text { - Absolute Bioavailability study } \\
\text { - Mass Balance study }\end{array}$ & $\begin{array}{l}\text { Class I, } \\
\text { Class III }\end{array}$ & $\begin{array}{l}\text { Class I } \\
\text { Rapidly Dissolving: } \geq 85 \% \text { of the labeled amount of the } \\
\text { drug substance dissolves within } 30 \text { minutes. } \\
\text { Class III } \\
\text { Rapidly Dissolving: } \geq 85 \% \text { of the labeled amount of the } \\
\text { drug substance dissolves within } 15 \text { minutes. } \\
\text { Apparatus: USP Type I at } 100 \mathrm{rpm} \text { or Type II at } 50 \mathrm{rpm} \\
\text { Dissolution Media: } 900 \mathrm{ml} \text { of following media } \\
\text { (1) } 0.1 \mathrm{~N} \mathrm{HCl} \text { or Simulated Gastric Fluid USP without } \\
\text { enzymes; } \\
\text { (2) pH } 4.5 \text { buffer; } \\
\text { (3) pH } 6.8 \text { buffer or Simulated Intestinal Fluid USP } \\
\text { without enzymes. } \\
\mathbf{N}=12\end{array}$ \\
\hline Brazil (7) & $\begin{array}{l}\text { Highest dose strength is } \\
\text { soluble in } \leq 250 \mathrm{ml} \text { of } \\
\text { buffers } \\
\text { pH range: } \\
\text { 1-6.8 } \\
\text { Temp.: } \\
37 \pm 1^{\circ} \mathrm{C}\end{array}$ & $\begin{array}{l}\text { Highly Permeable: Extent of } \\
\text { absorption in humans is } \geq \mathbf{8 5 \%} \\
\text { Methodology: } \\
\text { - Absolute Bioavailability study } \\
\text { - Mass Balance study } \\
\text { - In-vitro epithelial cell culture } \\
\text { study }\end{array}$ & Class I & $\begin{array}{l}\text { Rapidly Dissolving: } \geq 85 \% \text { of the labeled amount of the } \\
\text { drug substance dissolves within } 30 \text { minutes. } \\
\text { Apparatus: USP Type I at } 100 \mathrm{rpm} \text { or Type II at } 50 \mathrm{rpm} \\
\text { Dissolution Media: } 900 \mathrm{ml} \text { of following media } \\
\text { (1) } 0.1 \mathrm{~N} \mathrm{HCl} \text { or Simulated Gastric Fluid USP without } \\
\text { enzymes; } \\
\text { (2) } \mathrm{pH} 4.5 \text { buffer; }\end{array}$ \\
\hline
\end{tabular}




\begin{tabular}{|c|c|c|c|c|}
\hline $\begin{array}{l}\text { Regulatory } \\
\text { Authority }\end{array}$ & Solubility of Drug Substance & Permeability of Drug Substance & $\begin{array}{l}\text { BCS Class } \\
\text { of Drug } \\
\text { Substance }\end{array}$ & $\begin{array}{l}\text { In-vitro Dissolution Similarity of Test and Reference } \\
\text { Product }\end{array}$ \\
\hline & $\begin{array}{l}\text { Methodology: } \\
\text { - Shake Flask Method }\end{array}$ & & & $\begin{array}{l}\text { (3) } \mathrm{pH} 6.8 \text { buffer or Simulated Intestinal Fluid USP } \\
\text { without enzymes. } \\
\mathbf{N}=12\end{array}$ \\
\hline Canada $(8)$ & $\begin{array}{l}\text { Highest dose strength is } \\
\text { soluble in } \leq 250 \mathrm{ml} \text { of } \\
\text { buffers } \\
\text { pH range: } \\
\text { 1-6.8 } \\
\text { Temp.: } \\
37 \pm 1^{\circ} \mathrm{C} \\
\text { Methodology: } \\
\text { - Shake Flask Method or } \\
\text { similar method with } \\
\text { justification. }\end{array}$ & $\begin{array}{l}\text { Highly Permeable: Extent of } \\
\text { absorption in humans is } \geq \mathbf{8 5 \%} \\
\text { Methodology: } \\
\text { - Absolute Bioavailability study } \\
\text { - Mass Balance study }\end{array}$ & $\begin{array}{l}\text { Class I } \\
\text { and } \\
\text { Class III }\end{array}$ & $\begin{array}{l}\text { Class I } \\
\text { Rapidly Dissolving: } \geq 85 \% \text { of the labeled amount of the } \\
\text { drug substance dissolves within } 30 \text { minutes. } \\
\text { Class III } \\
\text { Very Rapidly Dissolving: } \geq 85 \% \text { of the labeled amount } \\
\text { of the drug substance dissolves within } 15 \text { minutes. } \\
\text { Apparatus: USP Type I at } 100 \mathrm{rpm} \text { or Type II at } 50 \mathrm{rpm} \\
\text { Dissolution Media: } 900 \mathrm{ml} \text { of following media } \\
\text { (1) } 0.1 \mathrm{~N} \mathrm{HCl} \text { or Simulated Gastric Fluid USP without } \\
\text { enzymes; } \\
\text { (2) pH } 4.5 \text { buffer; } \\
\text { (3) pH } 6.8 \text { buffer or Simulated Intestinal Fluid USP } \\
\text { without enzymes. } \\
\mathbf{N}=12\end{array}$ \\
\hline China & \multicolumn{4}{|c|}{ Guidance from Regulatory Authority of China is not available in Translated Language or English Language. } \\
\hline India (9) & $\begin{array}{l}\text { Highest dose strength is } \\
\text { soluble in } \leq 250 \mathrm{ml} \text { of } \\
\text { buffers } \\
\text { pH range: } \\
\text { 1-7.5 } \\
\text { Temp.: } \\
37 \pm 1^{\circ} \mathrm{C} \\
\text { Methodology: }\end{array}$ & $\begin{array}{l}\text { Highly Permeable: Extent of } \\
\text { absorption in humans is } \geq \mathbf{9 0 \%} \\
\text { Methodology: } \\
\text { - Absolute Bioavailability study } \\
\text { - Mass Balance study } \\
\text { - In-vivo perfusion study } \\
\text { - In-vitro excised human or }\end{array}$ & Class I & $\begin{array}{l}\text { Rapidly Dissolving: } \geq 85 \% \text { of the labeled amount of the } \\
\text { drug substance dissolves within } 30 \text { minutes. } \\
\text { Apparatus: USP Type I at } 100 \mathrm{rpm} \text { or Type II at } 50 \mathrm{rpm} \\
\text { Dissolution Media: } 900 \mathrm{ml} \text { of following media } \\
\text { (1) } 0.1 \mathrm{~N} \mathrm{HCl} \text { or Simulated Gastric Fluid USP without } \\
\text { enzymes; } \\
\text { (2) } \mathrm{pH} 4.5 \text { buffer; } \\
\text { (3) } \mathrm{pH} 6.8 \text { buffer or Simulated Intestinal Fluid USP }\end{array}$ \\
\hline
\end{tabular}




\begin{tabular}{|c|c|c|c|c|}
\hline $\begin{array}{c}\text { Regulatory } \\
\text { Authority }\end{array}$ & Solubility of Drug Substance & Permeability of Drug Substance & $\begin{array}{l}\text { BCS Class } \\
\text { of Drug } \\
\text { Substance }\end{array}$ & $\begin{array}{c}\text { In-vitro Dissolution Similarity of Test and Reference } \\
\text { Product }\end{array}$ \\
\hline & $\begin{array}{l}\text { - } \quad \text { Shake Flask Method } \\
\text { - } \quad \text { Acid or Base Titration }\end{array}$ & $\begin{array}{l}\text { animal Intestinal study } \\
\text { - In-vitro epithelial cell culture } \\
\text { study }\end{array}$ & & $\begin{array}{l}\text { without enzymes. } \\
\mathbf{N}=12\end{array}$ \\
\hline Japan (10) & \multicolumn{4}{|c|}{ Regulatory Authority of Japan has introduced the concept of BCS based Biowaiver but it hasn't particular guideline for that. } \\
\hline $\begin{array}{l}\text { Malaysia } \\
(11)\end{array}$ & $\begin{array}{l}\text { Highest dose strength is } \\
\text { soluble in } \leq 250 \mathrm{ml} \text { of } \\
\text { buffers } \\
\text { pH range: } \\
\text { 1-6.8 } \\
\text { Temp.: } \\
37 \pm 1^{\circ} \mathrm{C} \\
\text { Methodology: } \\
\text { - Shake Flask Method or } \\
\quad \text { similar method with } \\
\quad \text { justification }\end{array}$ & $\begin{array}{l}\text { Highly Permeable: Extent of } \\
\text { absorption in humans is } \geq \mathbf{8 5 \%} \\
\text { Methodology: } \\
\text { - Absolute Bioavailability study } \\
\text { - Mass Balance study }\end{array}$ & Class I & $\begin{array}{l}\text { Rapidly Dissolving: } \geq 85 \% \text { of the labeled amount of the } \\
\text { drug substance dissolves within } 30 \text { minutes. } \\
\text { Apparatus: USP Type I at } 100 \mathrm{rpm} \text { or Type II at } 75 \mathrm{rpm} \\
\text { Dissolution Media: } 900 \mathrm{ml} \text { of following media } \\
\text { (1) } 0.1 \mathrm{~N} \mathrm{HCl} \text { or Simulated Gastric Fluid USP without } \\
\text { enzymes; } \\
\text { (2) pH } 4.5 \text { buffer; } \\
\text { (3) pH } 6.8 \text { buffer or Simulated Intestinal Fluid USP } \\
\text { without enzymes. } \\
\mathbf{N}=12\end{array}$ \\
\hline Russia (12) & $\begin{array}{l}\text { Highest dose strength is } \\
\text { soluble in } \leq 250 \mathrm{ml} \text { of } \\
\text { buffers } \\
\text { pH range: } \\
\text { 1-6.8 } \\
\text { Temp.: } \\
37 \pm 1^{\circ} \mathrm{C} \\
\text { Methodology: } \\
\text { - Shake Flask Method or } \\
\quad \text { similar method with } \\
\quad \text { justification }\end{array}$ & $\begin{array}{l}\text { Highly Permeable: Extent of } \\
\text { absorption in humans is } \geq \mathbf{8 5 \%} \\
\text { Methodology: } \\
\text { - Absolute Bioavailability study } \\
\text { - Mass Balance study } \\
\text { - In-vivo perfusion study } \\
\text { - In-vitro excised human or } \\
\text { animal Intestinal study } \\
\text { - In-vitro epithelial cell culture } \\
\text { study }\end{array}$ & Class I & $\begin{array}{l}\text { Rapidly Dissolving: } \geq 85 \% \text { of the labeled amount of the } \\
\text { drug substance dissolves within } 30 \text { minutes. } \\
\text { Apparatus: USP Type I at } 100 \mathrm{rpm} \text { or Type II at } 75 \mathrm{rpm} \\
\text { Dissolution Media: } 900 \mathrm{ml} \text { of following media } \\
\text { (1) } 0.1 \mathrm{~N} \mathrm{HCl} \text { or Simulated Gastric Fluid USP without } \\
\text { enzymes; } \\
\text { (2) pH } 4.5 \text { buffer; } \\
\text { (3) pH } 6.8 \text { buffer or Simulated Intestinal Fluid USP } \\
\text { without enzymes. } \\
\mathbf{N}=12\end{array}$ \\
\hline
\end{tabular}




\begin{tabular}{|c|c|c|c|c|}
\hline $\begin{array}{c}\text { Regulatory } \\
\text { Authority }\end{array}$ & Solubility of Drug Substance & Permeability of Drug Substance & $\begin{array}{c}\text { BCS Class } \\
\text { of Drug } \\
\text { Substance }\end{array}$ & $\begin{array}{c}\text { In-vitro Dissolution Similarity of Test and Reference } \\
\text { Product }\end{array}$ \\
\hline $\begin{array}{l}\text { Saudi } \\
\text { Arabia (13) }\end{array}$ & $\begin{array}{l}\text { Highest dose strength is } \\
\text { soluble in } \leq 250 \mathrm{ml} \text { of } \\
\text { buffers } \\
\text { pH range: } \\
\text { 1-6.8 } \\
\text { Temp.: } \\
37 \pm 1^{\circ} \mathrm{C} \\
\text { Methodology: } \\
\text { - Shake Flask Method or } \\
\text { similar method with } \\
\text { justification }\end{array}$ & $\begin{array}{l}\text { Highly Permeable: Extent of } \\
\text { absorption in humans is } \geq \mathbf{8 5 \%} \\
\text { Methodology: } \\
\text { - Absolute Bioavailability study } \\
\text { - Mass Balance study } \\
\text { - In-vitro epithelial cell culture } \\
\text { study }\end{array}$ & Class I & $\begin{array}{l}\text { Rapidly Dissolving: } \geq 85 \% \text { of the labeled amount of the } \\
\text { drug substance dissolves within } 30 \text { minutes. } \\
\text { Apparatus: USP Type I at } 100 \mathrm{rpm} \text { or Type II at } 75 \mathrm{rpm} \\
\text { Dissolution Media: } 900 \mathrm{ml} \text { of following media } \\
\text { (1) } 0.1 \mathrm{~N} \mathrm{HCl} \text { or Simulated Gastric Fluid USP without } \\
\text { enzymes; } \\
\text { (2) pH } 4.5 \text { buffer; } \\
\text { (3) pH } 6.8 \text { buffer or Simulated Intestinal Fluid USP } \\
\text { without enzymes. } \\
\mathbf{N}=12\end{array}$ \\
\hline $\begin{array}{l}\text { South } \\
\text { Africa (14) }\end{array}$ & $\begin{array}{l}\text { Highest dose strength is } \\
\text { soluble in } \leq 250 \mathrm{ml} \text { of } \\
\text { buffers } \\
\text { pH range: } \\
\text { 1-7.5 } \\
\text { Temp.: } \\
37 \pm 1^{\circ} \mathrm{C} \\
\text { Methodology: } \\
\text { - Shake Flask Method or } \\
\quad \text { similar method with } \\
\text { justification }\end{array}$ & $\begin{array}{l}\text { Highly Permeable: Extent of } \\
\text { absorption in humans is } \geq \mathbf{9 0 \%} \\
\text { - Absolute Bioavailability study } \\
\text { - Mass Balance study } \\
\text { - In-vitro epithelial cell culture } \\
\text { study }\end{array}$ & Class I & $\begin{array}{l}\text { Rapidly Dissolving: } \geq 85 \% \text { of the labeled amount of the } \\
\text { drug substance dissolves within } 30 \text { minutes. } \\
\text { Apparatus: USP Type I at } 100 \mathrm{rpm} \text { or Type II at } 50 \mathrm{rpm} \\
\text { Dissolution Media: } 900 \mathrm{ml} \text { of following media } \\
\text { (1) } 0.1 \mathrm{~N} \mathrm{HCl} \text { or Simulated Gastric Fluid USP without } \\
\text { enzymes; } \\
\text { (2) pH } 4.5 \text { buffer; } \\
\text { (3) pH } 6.8 \text { buffer or Simulated Intestinal Fluid USP } \\
\text { without enzymes. } \\
\mathbf{N}=12\end{array}$ \\
\hline
\end{tabular}

(Note: * Recently US FDA proposed draft guidance on "Waiver of In-vivo Bioavailability and Bioequivalence studies for Immediate Release Solid Oral Dosage Forms based on a Biopharmaceutics Classification System - Guidance for Industry" (May 2015). As per this guidance, BCS class I as well as BCS class III drugs can get Biowaiver approval. Moreover, the same requirements from EU guidance for $\mathrm{pH}$ range for solubility study, extent of absorption and dissolution criteria have been proposed.) 


\section{CONCLUSION}

It is concluded that the Biowaiver is an advantage for generic companies as it exempts BE study. In addition, Biowaiver is a time and cost saving fast track approach for ANDA filing. BCS based Biowaiver is employed to waive In-vivo BE testing for new as well as generic drugs application. Granting Biowaivers under systems such as the BCS eliminates unnecessary In-vivo studies and provides fast approval, while maintaining the high public health standard for therapeutic equivalence to the innovator drug. Using the rationale of BCS, it can be argued that Biowaivers can also be granted on the basis of standard pharmacokinetic data, such as when a drug exhibits dose-linear pharmacokinetics and a sufficiently fast dissolution profile. However, BCS based Biowaiver does not apply to food effects bioavailability studies and other pharmacokinetic studies as they are intended only for BE studies. Thus, BCS based Biowaiver is not applicable to waive all types of clinical studies.

Research is ongoing in this field by exploring different strategies and methods to increase the utilization of the Biowaiver approach (mostly BCS based Biowaiver). In the future, the Biowaiver monograph project will extend to fixed dose combinations and science based risk calculations. However, further global harmonization for Biowaiver regulations and guidelines is needed for wider implementation of best science practices in the area of Biowaiver.

\section{ACKNOWLEDGEMENT}

I'm thankful to Dr. Priti Mehta, Dept. of Pharmaceutical Analysis, Institute of Pharmacy, Nirma University, India, \& Ms. Vaishali Kothari, International Regulatory Affairs, Cadila Healthcare Limited, New Sigma PTC, Ahmedabad for his kind assistance for the preparation of this manuscript.

\section{CONFLICTS OF INTEREST}

Author declares that there are no conflict of interest in this work.

\section{REFERENCES}

1. USFDA [Internet]. FDA; 2003 [cited 2015 Feb]. Available from:

http://www.fda.gov/downloads/Drugs/Guidances/ucm07 0124.pdf.

2. Nair AK. Statistics on BCS Classification of Generic Drug Products Approved Between 2000 and 2011 in the USA. AAPS Journal. 2012 June; 14: p. 664-6.

3. USFDA [Internet]. FDA; 2000 [cited 2015 Jan 15]. Available from:

http://www.fda.gov/downloads/Drugs/Guidances/ucm07 0246.pdf

4. EMEA [Internet]. EMA; 2010 [cited 2015 Jan 18]. Available from:

http://www.ema.europe.eu/docs/en_GB/document_librar y/Scientific_guideline/2010/01/WC500070039

5. WHO [Internet]. [cited 2015 Jan 15]. Available from: www.WHO.com

6. hsa.gov [Internet]. HSA. ASEAN; 2004 [cited 2015 Jan 20]. Available from:

http://www.hsa.gov.sgt/content/dam/HSA/HPRG/Wester n_Medicine/Overview_Framework_policies/Guidelines_ on_Drug_Registration/ACTR_GuidelinesforConductofB ioavailabilityandBioequivalenceStudies.pdf

7. anvisa.gov.br [Internet]. ANVISA, Brazil;2006 [cited 2015 Jan 25]. Available from:

http://www.puntofocal.gov.ar/notific_otros_miembros/br a226_t.pdf

8. Healthcanada.gc.ca [Internet]. Healthcanada; 2014 [cited 2015 Jan 23]. Available from:

http://www.hc-sc.gc.ca/dhp-mps/prodpharma/applicdemande/guideld/bcs_guide_ld_scb-eng.php

9. CDSCO [Internet]. CDSCO; 2005 [cited 2015 Feb 4]. Available from:

http://cdsco.nic.in/html/be\%20guidelines\%20drafts\%ver 10\%20march\%2016,\%2005.pdf

10. MHLW. NIHS. [Internet].Division of Drugs; 2012 [cited 2015 Feb 3]. Available from:

http://www.nihs.go.jp/drug/be-guide(e)Generic/GLE_120229_BE_rev140409.pdf

11. Ministry of Health, BPFK [Internet]. National Pharmaceutical control bureau; 2013 [cited 2015 Feb 12]. Available from:

http://portal.bpfk.gov.my/aeimages/file/guidance_on_bio pharmaceutics_classification_system_bcs_based_Biowai ver.pdf

12.FIP, Russia [Internet]. International Pharmaceutical Federation ; 2011 [cited 2015 Jan 25]. Available from: http://www.fip.org/files/fip/BPS/BCS/Biowaiver\%20gui dance $\% 20(\mathrm{ru}) \% 20 \% 20 \mathrm{ENG} \% 20 \mathrm{March} \% 202011$.pdf

13.SFDA [Internet]. SFDA; 2012 [cited 2015 Jan 26]. Available from:

http://www.sfda.gov.sa/en/drug/drug_reg/Regulations/G uidelines $\% 20$ for $\% 20 \mathrm{BCS} \% 20$ based $\% 20$ Biowaiver $\% 20 \mathrm{~S}$ FDA\%20(8-4-2013).pdf

14. ICH.org [Internet]. SADC. ICH; 2007 [cited 2015 Jan 26]. Available from:

http://www.ich.org/fileadmin/public_Web_site/ABOUT _ICH/Organization/SADC.pdf . 